\section{Jakob Arvola}

Forfatter og journalist

Foto: Privat

\title{
Se på meg
}

\section{Jeg blir så nervøs av mennesker som ikke møter blikket mitt, hva kan det være, doktor?}

Mai 1990. Det lå en reseptblokk på bordet, en penn, et stetoskop og en fyldig bunke skjemaer med fritak fra repetisjonsøvelse, det var alt. Og den bunken hadde det ikke gått mange ark av, kunne jeg se. Mannen foran meg satt med armene i kors: Lege og løytnant i Forsvarets tjeneste. Blikket hans sto rett i øynene mine. Han vek ikke ett sekund, og det var en klokke på veggen der sekundviserne hamret inn tiden.

Jeg var tjuetre år gammel, og neimen om jeg hadde lyst til å være tre uker på rep. Ikke hadde jeg tid, ikke hadde jeg ork, og dessuten var det unødvendig, mente jeg: Det var bare få år siden jeg hadde dimmet fra førstegangstjenesten, jeg hadde ikke glemt noe, og dessuten var den kalde krigen på hell, Gorbatsjov styrte kommunismen mot avvikling, og dermed var tre uker på fjellet bortkastet tid for alle, mente jeg. I ettertid ser jeg at det politiske motivet var ganske løst fundamentert.

Jeg hadde gått alle formelle kanaler: Protestert, skrevet brev, ringt, til og med hjem til kringkastingssjef Einar Førde for å få ham med på laget, jeg var nyansatt i NRK og mente at dette måtte vel Kringkastingen kunne ordne opp i.

- Eg trur ikke at eg kan hjelpe med dette, Arvola. Forresten er det laurdagskvelden. Du får ha det fint på fjellet. NRK skal vel klare seg, svarte sjefen.

Mandag morgen i leiren: I et siste forsøk på fritak hadde jeg gnidd øynene inn med sitronsaft. Meldt meg hos militærlegen. Og det var der jeg satt nå, med det forlokkende skjemaet som kunne forkynne fritak på bordet foran meg. Alt legen behøvde å gjøre, var å gripe pennen og tro på forklaringen min om at jeg var allergisk mot et eller annet, sende meg ut døren som en fri mann med skjemaet i hånden, det jeg triumferende kunne levere på kompanikontoret og saken ville vært ute av verden.

Men han satt bare der og så meg inn i øynene. Han hadde hørt forklaringen min, øynene mine var hovne, det rant snørr av meg, og jeg så ikke ut. Men han så inn, i meg, han så rett inn i dypet av den nattsvarte løgnen som jeg nettopp hadde plantet i konge og fedreland, og klokken på veggen tikket, og jeg svelget, og han bare kikket på meg, tiden falt lang, og så sa han de forløsende ord:

- Og hva tror du at du skal oppnå med dette? Meld deg på intendanturen, hent ut uniformen din. Kom deg ut, og kast ikke bort tiden min.

Legevakta i en norsk kommune, høsten 2014. Jeg er for lengst ute av den tiden der Forsvaret kan plukke meg inn til rep. Sluttet å bløffe legestanden har jeg også gjort. Men halsen verker, magemusklene er steinharde etter flere netters hostekule. Legen foran meg stirrer inn i en skjerm. Han har hilst kort på meg i døren, og satte seg deretter rett ned ved terminalen. Og der sitter han nå. Jeg ser ham bare i profil. Jeg forteller ham om Noskapin-tablettene som virker en times tid før det er på'n igjen med nye hosteanfall. Han svarer «mhm» og ser inn i skjermbildet. Han har lyttet på brystet, men har ikke sett på meg under lytteøvelsen, bare mumlet «mhm» og sett videre inn i skjermen.

Jeg tar meg i å lure på hva han kikker på. Som journalist blir jeg nysgjerrig: Har det skjedd noe alvorlig i verden, leser han nettaviser, eller skriver han kanskje et blogginnlegg? Leter han etter en diagnose, eller laster han ned en film? Han fortsetter med sine «mhm»før konklusjonen:

- Resept på Cosylan. Du kan levere den på apoteket.

Deretter er konsultasjonen over, vi har ikke vekslet et eneste blikk. I det øyeblikket skjønner jeg at jeg kunne vært hvemsomhelst, jeg kunne bedt om hvasomhelst, han kunne like gjerne lagt kabal der på skjermen, og han kunne like gjerne ha svart, som løytnantslegen, at jeg fikk se til å komme meg ut og ikke kaste vekk tiden hans.

Forskjellen er at løytnanten så meg. Han så på meg, det var papir på bordet, og internett og intranett var noe det amerikanske forsvaret drev med i hemmelighet, mens en alminnelig norsk feltlege måtte stole på egne øyne.

Det er ikke nødvendig å se på hverandre mer, har jeg forstått.

Og i dag ville jeg gladelig takket ja til tre uker på fjellet på rep.

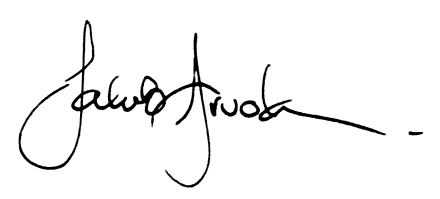

